\title{
No ritmo da industrialização da cultura: cinemanovistas e o jornalismo televisivo (1971-1973)
}

\author{
Igor Sacramento ${ }^{1}$ \\ ECO/UFRJ
}

\begin{abstract}
Resumo: Este artigo estuda as condições que possibilitaram a associação de cinemanovistas ao jornalismo televisivo, a partir da inédita experiência da série de documentários Globo-Shell Especial que se deu entre 1971 e 1973 e foi precursora do Globo Repórter. Publicadas em O Globo e em Filme Cultura, as impressões de Geraldo Sarno, Gustavo Dahl, Paulo Gil Soares e Walter Lima Júnior sobre os seus trabalhos para o programa ajudam tanto a discutir a respeito da (re)inserção institucional de artistas de esquerda à industria cultural quanto acerca da aproximação de dois campos relativamente autônomos - cinema e televisão.
\end{abstract}

Palavras-chave: cinemanovistas; indústria cultural; televisão; jornalismo.

\begin{abstract}
This article studies the conditions that made possible the association between cinemanovistas and the television journalism area, from the inedited experience of the Globo-Shell Especial documentary series produced the between 1971 and 1973. This program was the precursor of the Globo Repórter. Published in O Globo and in Filme Cultura, the impressions of Geraldo Sarno, Gustavo Dahl, Paulo Gil Soares e Walter Lima Júnior regarding their works for the program as much help to raise the question the institutional (re)including of revolutionary artists to the culture industry as to the approximate of two relatively autonomous fields - cinema and television.
\end{abstract}

Key words: cinemanovistas; culture industry; television; journalism.

\footnotetext{
1 Bacharel em jornalismo pela Escola de Comunicação da Universidade Federal do Rio de Janeiro (ECO/UFRJ) e mestrando em Comunicação e Cultura pela mesma instituição. Atualmente, dedica-se à escritura de sua dissertação, "Depois da revolução, a televisão: cineastas de esquerda no jornalismo televisivo (1971-1986)", em que estuda a presença e a participação de cineastas identificados com o Cinema Novo nos programas Globo-Shell Especial e Globo Repórter.
} 
Resumen: Eso artículo estudias las condiciones que posibilitaron la asociación de cinemanovistas (cineastas de "Nuevo Cinema") al periodismo televisivo, a partir de la inédita experiencia de la serie de documentarios Globo-Shell Especial que ocurrió mientras 1971 y 1973 y fue precursora del Globo Repórter. Publicadas en O Globo e en Filme Cultura, las impresiones de Geraldo Sarno, Gustavo Dahl, Paulo Gil Soares e Walter Lima Júnior sobre sus trabajos para el programa ayudan tanto a discutir acerca da (re)inserción institucional de artistas revolucionarios à industria cultural cuanto sobre la aproximación de dos campos relativamente autónomos cinema e televisión.

Palabras-clave: cinemanovistas; industria cultural; televisión; periodismo.

Résumé: Cet article étudie les condiciones que permettent l'association des cinemanovistas (cinéastes de "Nouvelle Cinéma») au journalisme de télévision, à partir de la expériencé de la série de documentarie Globo-Shell Especial réalisée entre 1971 e 1973 et que précéde le Globo Repórter. Publiées dans $O$ Globo et dans Filme Cultura, les impressions de Geraldo Sarno, Gustavo Dahl, Paulo Gil Soares e Walter Lima Júnior au sujet des oeuvres destinées au programmee aident à la fois à commeter sur la (re)introduction institucionalle de les artistes revolucionnares à l'industrie culturelle et sur rapprochement de deux domaines rélativement autonomes, à savoir le cinéma e la télévision.

Mots-clé: cinemanovistas; industrie culturelle; télévision ; journalisme.

No dia 14 de novembro de 1971, domingo, estreou a série Globo-Shell Especial, com o documentário Verdade sobre a Transamazônica. Coordenada pelo diretor da Central Globo de Jornalismo da época, Armando Nogueira, a equipe pretendia desvendar os mistérios acerca da construção da rodovia e mostrar como vivem as pessoas que nela trabalhavam e que por ela tiveram suas rotinas alteradas, destacando os atos heróicos de todos os envolvidos. O jornal $O$ Globo, em nove de outubro daquele ano, já anunciava que série contaria com mais dezesseis documentários além desse: esportes, arte popular, habitação, turismo, arquitetura, projeto Rondon, comunicação, educação, música popular, saúde, eletrificação e natal eram alguns dos outros temas. 
Programado para ser exibido, às 22 horas e 30 minutos, depois de Buzina do Chacrinha, o Globo-Shell Especial empolgou a crítica televisiva: "É o início de uma nova mentalidade em tevê e que a gente pode fazer assim: mais vale gastar com o Brasil do que com aquele abraço" (O Globo, 13/11/1971: 12). A referência ao programa de Abelardo Barbosa, o Chacrinha, pelo título homônimo da música de Gilberto Gil demonstra o desgosto por parte de intelectuais, de artistas, de militares e de religiosos em relação à "excessiva popularização" dos programas televisivos. Com uma "nova mentalidade" em vigor, certos tipos de formato tinham de ser abandonados.

Em 1972, no ensaio que inaugura o debate acadêmico sobre televisão no Brasil, Muniz Sodré (1978) identifica com o "grotesco escatológico" a grande parte dos programas populares da televisão brasileira da época, especialmente os de auditório. Eles são definidos dessa maneira por abusarem da indistinção entre o cômico, o caricatural e o monstruoso. Sodré (1978: 73-74) caracterizou assim alguns desses programas:

Sílvio Santos, em Rainha por um Dia [quadro do Programa Sílvio Santos, exibido na TV Globo de 1968 a 1976] promovia o desfile de miseráveis, que contavam suas penas. Cabia ao auditório escolher a história mais triste. A mais desgraçada, a mais infeliz, era eleita "Rainha por um dia". Jacinto Figueiras Júnior, que apresentou no Rio [TV Globo] e em São Paulo [TV Cultura] o programa $O$ Homem do Sapato do Branco, levou à televisão prostitutas, ladrões e homossexuais, chegando a realizar uma "mesa-redonda com mendigos". Dercy Gonçalves [em Dercy de Verdade na TV Globo] explora também a miséria, os temas de baixo espiritismo, os curandeiros, as irmãs xifópagas, as aberrações e as deformidades físicas. Raul Longras explorava [em programas como SOS Amor, também da Globo] o tema da infelicidade: mulheres que não conseguiam casar-se eram expostas aos telespectadores, que se compraziam com as diversas fases do romance.

Como se pode notar, a TV Globo detinha o maior número de programas "grotescos". A emissora, que não surgiu líder de audiência, investiu nesse tipo de programação como um esforço para conquistar a liderança. João Freire Filho (2005: 168-170) expõe o desconforto da imprensa com os programas que retratassem o "mundo cão" e argumenta que, somada às pressões dos governos militares, a virulência das críticas em relação à televisão fez com que ela se reorientasse em busca de uma "programação de qualidade". 
Maria Celeste Mira (1995: 30-52) e Sonia Wanderley (78-110) concordam que a década de 1970, diferente da anterior, foi o momento decisivo dessa mudança, tomada com mais empenho pela Rede Globo. Por estar vinculada à ditadura militar, ela deveria se preocupar com novas maneiras de representar o "homem brasileiro". A imagem deveria ser estar afinado com os tempos de modernização, desfazendo de elementos enraizados nas formas populares de diversão. O ano de 1973 foi o marco simbólico do reposicionamento, com a chegada da cor aos programas da emissora.

Dois anos antes, a série Globo-Shell Especial exemplifica a tendência das mudanças: o investimento na área jornalística. Como lembram Ana Paula Goulart Ribeiro e Marialva Barbosa (2005: 214), na primeira metade dos anos 1970, surgiram o Jornal Hoje (1971), Globo-Shell Especial (1971), o Globinho (1972), Jornal Internacional (1972), Globo Repórter (1973) e Fantástico (1973). Isto sem falar no Jornal Nacional, que, já em 1969, anunciava a virada da emissora. Na segunda metade daquela década, estrearam ainda Amanhã, Bom Dia São Paulo, Jornal da Globo, Jornal das Sete e Painel.

Carlos Magaldi, um dos sócios da empresa de publicidade Magaldi \& Maia, cuidava da conta da Shell. A empresa de petróleo estava interessada em produzir documentários sobre o Brasil e comprou uma faixa de horário da Rede Globo que, num primeiro momento, funcionaria apenas como exibidora dos filmes produzidos ou comprados por ela. A Blimp Filmes, produtora de Carlos Augusto de Oliveira, irmão de José Bonifácio de Oliveira Sobrinho (o Boni), era o principal pólo de produção.

Paulo Gil Soares ficou responsável por coordenar a realização dos documentários. Em 1971, o diretor de arte de filmes de Glauber Rocha (Deus e o Diabo na Terra do Sol, Terra em Transe e O Dragão da Maldade contra o Santo Guerreiro) aproveitou os seus contatos e convidou Domingos Oliveira, Geraldo Sarno, Gustavo Dahl, Maurice Capovilla e Walter Lima Júnior para participarem do projeto. A partir de 1973, Paulo Gil convidou Dib Lutfi, Eduardo Coutinho e João Batista de Andrade para fazerem parte da equipe do Globo Repórter que também contou com Maurice Capovilla e Walter Lima Júnior, além de participações esporádicas de David Neves, Roberto Santos e Sylvio Back. Acreditando que para poder falar do Brasil na televisão era preciso contar com cineastas, Paulo Gil, para $O$ 
Globo (21/07/1974: 12), lembrou do projeto que originou o Globo Repórter e disse: "A gente pensou em fazer um enfoque cinematográfico da realidade brasileira e em trazer o pessoal do cinema para fazer esse negócio na televisão". Como podemos notar, a maioria dos cineastas identificava-se com o Cinema Novo.

A Maria Rita Khel (1986: 249), Walter Lima Júnior disse:

É bem provável que o incidente com a apresentação do Seu Sete da Lira no programa do Chacrinha não tenha sido o principal determinante da criação do Globo Shell (futuro Globo Repórter) e, mais tarde, do Fantástico, em 1973, consolidando o que já vinha sendo a diretriz fundamental de toda a programação produzida dentro da emissora.

Em 29 de agosto de 1971, num domingo, os programas Buzina do Chacrinha, da TV Globo, e Programa Flávio Cavalcanti, da TV Tupi, exibiram a mãe-de-santo Dona Cacilda de Assis, que dizia receber o espírito de Seu Sete da Lira. O Exu da Umbanda se apresentou primeiro em um e, depois, no outro. O episódio provocou duras reações. Os videoteipes dos programas foram apreendidos pela Polícia Federal. Diante do ocorrido, o ministro das Comunicações Hygino Corsetti ventilou a possibilidade de cassar a concessão das emissoras que utilizassem o "sensacionalismo" e a "baixaria" como estratégia de mercado. Aconteceu, porém, que ele se limitou a anunciar que o governo tinha a intenção de acabar com as transmissões ao vivo na televisão brasileira e de nomear uma comissão interministerial com a responsabilidade de fixar, no prazo de um mês, normas de conduta para as emissoras. Antecipando-se às medidas governamentais, Globo e Tupi assinaram um protocolo de autocensura. Na Globo, a nova série de documentários que entrou no ar pouco mais de dois meses dois anunciava os novos tempos - de Padrão Globo de Qualidade.

A televisão transmitida em rede para telespectadores de vários lugares do país só foi possível com o advento do Estado militar, que, além de sua dimensão política (autoritarismo, repressão e censura), como argumenta Renato Ortiz (2001: 114), promoveu transformações profundas no nível da economia, consolidando no Brasil o chamado "capitalismo tardio". Depois do golpe militar, ao mesmo tempo em que cresciam a indústria nacional e o mercado interno de bens materiais, fortaleciam-se o parque industrial de produção de cultura e o seu mercado de consumo. Como exemplo do investimento dos militares na promoção da integração 
nacional pela comunicação, em 1965, a Empresa Brasileira de Telecomunicações (Embratel) é inaugurada. Isto, a partir de 1969, possibilitou a constituição de redes nacionais de televisão no país, transmitida em microondas. Em primeiro de setembro de 1969 daquele ano, vai ao ar o Jornal Nacional, o primeiro programa televisivo transmitido para todo o país, graças à infra-estrutura tecnológica fornecida pela estatal.

Nesse momento, a ditadura militar cobrou o fim do "espetáculo degradante" (ORTIZ: 2001, 120) que dominava os programas. Era preciso formar um homem brasileiro como estava previsto na doutrina de Segurança Nacional, que era embasada num universo de valores ligados a um cristianismo extremamente conservador, tendo a família, a religião, a moral e bons costumes, a pátria e a propriedade como os pilares da ordem social. Para isso, os meios de comunicação tinham de aprimorar e internalizar os valores do grupo social dirigente.

Para se livrar do "grotesco", a Rede Globo se empenhou numa "política de recrutamento de toda uma geração de técnicos, escritores e artistas comprometidos com a ética e a estética de esquerda" (MICELI: 1994, 60). Os artistas da revolução nacional-popular forjada nos anos 1960 estavam mais habilitados à produção de programas condizentes com os padrões estéticos do gosto do "novo perfil do consumidor brasileiro" (MIRA: 1995, 45), uma vez que suas obras agradavam o público intelectualizado e das grandes metrópoles. Todavia, tal "cooptação" deve ser percebida levando em conta as diferentes maneiras pelas quais os cineastas entenderam a sua presença na televisão.

Exibido em 19 de março de 1972, Arquitetura: a Transformação do Espaço foi o primeiro documentário televisivo de Walter Lima Júnior. Em entrevista, o diretor de Menino de Engenho (1965) não titubeou ao afirmar o seu fascínio pela televisão e disse em entrevista para $O$ Globo (17/03/1972: 09), acreditando que na nova mídia também é possível ter "liberdade de autoria":

Já há algum tempo eu estava interessado em fazer filme para a televisão. Mas a televisão era ainda um caminho fechado para nós, homens de cinema. Com a série Globo-Shell Especial, este caminho se abriu. Um caminho sensacional, tão sensacional como a própria televisão. Me deram um tema, arquitetura, também sensacional. E me deram o que considero mais importante: absoluta liberdade para 
realizar o filme. Eu trabalhei livremente e o pessoal da produção só viu o filme depois de pronto.

Esta fala de Walter Lima Júnior remonta à idéia de "cinema de autor" que, no Brasil, foi forjada pelo Cinema Novo. Jean-Claude Bernardet (1994: 11) relaciona o debate da autoria no cinema brasileiro com o da novelle vague, mas provoca. Ele não esquece que Hollywood é geralmente tida como o lugar do comércio, do divertimento, do cinema de massa e nunca como lugar da arte e da autoria, mesmo que tenha sido esse tipo de produção cinematográfica que mais aplicou a política dos autores. A autoria, todavia, deve ser definida pela liberdade, pela ausência de coerções de qualquer tipo, deve ser um instrumento político de contestação.

De modo semelhante, Heloísa Buarque Hollanda e Marcos Gonçalves (1982: 37-38) também notaram aquela diferença e foram mais contundentes, afirmando que a idéia de cinema de autor consiste numa ruptura com "os constrangimentos das grandes produções". Busca pela a existência de um autor como "dono do estilo", da história e da problemática do filme, podendo, assim, assumir as mais variadas posições políticas.

Dessa forma, a liberdade de autoria conjugada a uma visão política de esquerda - não necessariamente partidária - foi compartilhada, de diferentes maneiras, por um heterogêneo grupo de cineastas brasileiros. O sentimento de construir, num primeiro momento, um cinema livre do mercado e das coerções do dogmatismo partidário ou institucional atrelado à busca por analisar e por transformar radicalmente a realidade do país ganhou diversos adeptos, mesmo que nem todos fossem reconhecidos como tais.

Partindo de um diálogo com o neo-realismo italiano, com a novelle vague $\mathrm{e}$ com escritores brasileiros, os filmes Rio 40 graus (1955), Rio Zona Norte (1957) e Vidas secas (1963), de Joaquim Pedro de Andrade; Aruanda (1960), de Linduarte Noronha; Deus e o Diabo na Terra do Sol (1963), de Glauber Rocha; e Os Fuzis (1963), de Ruy Guerra, são fundadores da estética cinemanovista (cf. BERNARDET, 1967; SALLES GOMES, 1995; XAVIER, 2001) ao lado da produção da época de Arnaldo Jabor, Cacá Diegues, David Neves, Eduardo Coutinho, Gustavo Dahl, Leon Hirzman, Luiz Carlos Barreto, Paulo César Saraceni e Walter Lima Júnior. Embora sem o reconhecimento deste grupo, o fundador, obras de cineastas herdeiros da velha 
estética da Vera Cruz - Anselmo Duarte, Roberto Faria e Roberto Santos - assim como dos que se formavam cineastas em São Paulo no momento da eclosão do Cinema Novo (Francisco Ramalho, João Batista de Andrade, Luiz Sérgio Person, Maurice Capovilla e Renato Tapajós) também faziam parte "estrutura de sentimento de filmes do Cinema Novo" (cf. RIDENTI, 2005), uma vez que suas obras eram caracterizadas pela valorização da identidade brasileira arraigada no homem simples do povo (do campo ou habitante da periferia das grandes cidades), pela denúncia das desigualdades sociais e pela busca do desvendamento da realidade brasileira. Cineastas com "projetos isolados" (RAMOS: 2004, 82) como Domingos Oliveira, Sylvio Back e Walter Hugo Khouri também compartilharam propostas em comum com o Cinema Novo, como a questão da autoria, mesmo rivalizando com outras, como a necessidade fazer um filme político no sentido de revolucionário.

Os 50 minutos de Arquitetura: a Transformação do Espaço foram divididos em três movimentos. No primeiro, é exibida uma síntese da história da arquitetura brasileira e de seus contatos com a arquitetura internacional. Depois, arquitetos como Burle Marx, Grigori Warchavchik, Joaquim Cardoso e Lina Bo Bardi depõem sobre a crise em sua profissão. No terceiro, habitantes de várias cidades brasileiras falam sobre o espaço em que vivem. Neste momento, são entrevistados peões, estudantes e transeuntes, situados em Brasília, que revelam as crueldades do projeto modernista, que, além das mortes dos trabalhadores, levou a uma violenta segregação sócio-especial.

Antes da televisão, Walter havia sido assistente de direção de Glauber Rocha em Deus e o Diabo na Terra do Sol, o que o deixou mais próximo das discussões de cinema e realidade nacional à maneira feita pelo Cinema Novo. Na Rede Globo, ficou até 1986, dirigindo documentários e reportagens para o Globo Repórter, quando o Globo-Shell Especial deixou a grade da emissora em 1973. Sobre a relação entre cineastas brasileiros e a televisão, Walter Lima Júnior continuou a sua explanação para a reportagem de $O$ Globo:

Para nós, homens do cinema brasileiro, essa oportunidade aberta pela série Globo-Shell é muito importante, pois nos permite mostrar nossa capacidade em realizar filmes sobre a realidade de nosso país para serem visto pelo público de nosso país. Essa e outras séries semelhantes poderão criar uma nova mentalidade para a própria 
televisão brasileira e abrir novas oportunidades para os profissionais de cinema.

Neste trecho, vemos a empolgação com as possibilidades da televisão, que como um meio de maior público que o cinema, seria capaz de desvelar a realidade brasileira para a maioria dos brasileiros, o que não era possível com o grande écran. No entanto, estas oportunidades só foram abertas no momento em que a televisão se consolida como o meio de comunicação estratégico para a política cultural do Estado autoritário, coincidindo com a renovação da programação das emissoras de TV. Especialmente, os cinemanovistas passaram a se dedicar a projetos cada vez mais individuais e se mostraram ainda mais preocupados com o mercado, com a indústria e com suas carreiras, acredito que não se apagaram as posições defendidas coletivamente anteriormente. Todavia, a abertura do caminho para a entrada de cineastas para a televisão relaciona-se também à industrialização da produção cinematográfica brasileira.

Num artigo, Marcos Napolitano (2001: 104) acrescenta identifica que incipiente sistema cultural "artista-obra-público" não conseguia a popularidade esperada, mas, ao contrário, cada vez mais que não se limitava ao jovem estudante universitário. Embora o Cinema Novo tenha tido - e ainda tem - uma enorme influência no meio artístico e intelectualizado, seus filmes não conseguiram ter um significativo êxito de público, apesar de eles terem tido a intenção de conscientizar o povo ao mostrar as profundezas do Brasil. Então, num tempo de consolidação da lógica da indústria cultura e da expansão dos seus segmentos, surgia a vontade de "ir ao mercado", impulsionada pelo golpe militar de 1964 e, principalmente, pelo Ato Institucional $\mathrm{n}^{0} 5$ (AI-5), de 13 de dezembro de 1968. O autor prefere o verbo "impulsionar" para enfatizar que a discussão da conquista do público popular, do povo, dominava os debates dos artistas engajados desde o final dos anos 1950. O “segundo golpe", porém, recrudesceu a repressão às expressões contraditórias ao regime. Afinal, como estuda Inimá Simões (1999: 71-249), não se podia tratar das mazelas do Brasil e nem faltar com "a moral e os bons costumes" em tempo de milagre brasileiro.

A partir do golpe de 1964 e, principalmente, de 1968, começam a se dissolver as condições históricas da estrutura de sentimento da brasilidade revolucionária 
frente à consolidação da modernização conservadora capitaneada por um Estado autoritário ambíguo que, como considera Marcelo Ridenti (2005: 98), “com a mão direita punia duramente os opositores que julgava mais ameaçadores - até mesmo artistas e intelectuais -, e com a outra atribuía um lugar dentro da ordem não só aos que docilmente se dispunham a colaborar, mas também a intelectuais e artistas da oposição". Por exemplo, novos caminhos se abriram para os cineastas. O Estado, representado pela Empresa Brasileira de Filmes (Embrafilme), e a televisão, pela Rede Globo, foram os mais seguidos. Como bem diz Paulo Emílio Salles Gomes (1996: 103-104), o Cinema Novo não resistiu ao impacto da ditadura militar e se desmantelou em projetos individuais, voltando-se para si próprio, para seus realizadores e para o seu público - jovem estudante de esquerda.

Cineastas provenientes do Cinema Novo começaram a estabelecer relações com a Embrafilme, criada em 1969, assumindo cargos, pressionando pela adoção de determinadas políticas e se beneficiando delas. Podemos entender o aparente paradoxo dessa aproximação, se lembrarmos das observações de José Mário Ortiz Ramos (1983: 55), que aponta para o fato de a "esquerda cinematográfica”, desde os anos 1960, acreditar que o grande responsável pelo desenvolvimento da indústria cinematográfica brasileira deveria ser o Estado, promovendo sanções aos interesses do capital internacional e investindo numa produção nacional, subdesenvolvida.

Aconteceu, porém, que o envolvimento desses cineastas com a Embrafilme, como mostra Marina Soler Jorge (2002), não implicou meramente na aceitação da visão cultural oficial, mesmo que a intenção maior deles tenha sido conquistar o público que não havia conquistado na década anterior. A ênfase na produção de filmes de caráter popular, eles não tinham a intenção de produzir pornochanchadas produção dominante na empresa -, mas "filmes culturais", como opta por chamar a autora. As produções, além da censura do governo, sofriam a censura do "potencial de mercado". Normalmente, eram aprovados os projetos que tivessem "um forte apelo popular". Jorge (2002: 66) completa: “É importante atentarmos para o que, no relacionamento dos ex-cinemanovistas com o Estado, orientou uma perigosa de censura: a intolerância da pornochanchada". A autora percebe que tal rótulo foi uma estratégia de diferenciação por parte daqueles cineastas. Como ela conclui, todos 
aqueles que não haviam compartilhado das propostas cinemanovistas não mereciam lugar de destaque nas discussões sobre os caminhos do cinema nacional.

Por tudo isso, o Cinema Novo entrou na moda. Os sentimentos compartilhados pelos cinemanovistas no Rio de Janeiro não se restringiram somente a eles. Em outras palavras: o sentimento de pertencimento não foi vivido unicamente pelos cariocas, mas por paulistas também. Isso demonstra, portanto, a supremacia e a distinção do Cinema Novo no campo do cinema brasileiro daquela época. Era um cinema de prestígio, distinto e dominante no campo do cinema brasileiro, se optarmos pelo vocabulário de Pierre Bourdieu (2001).

José Mário Ortiz Ramos (2004: 26) explica que, ao longo dos anos 1960 e 1970, o mercado cinematográfico do país foi marcado pela "expansão da grife do cinema culto", entendendo como dilatação do projeto original do Cinema Novo, principalmente, e de setores do Cinema Marginal e como ampliação e diversificação de suas bases, absorvendo outras temáticas e entrando em outras mídias. Ramos (2004: 98) também chama a atenção para o fato de que a oposição entre um "cinema artesanal" e uma "televisão fabril" se tornou cada vez menos latente, uma vez que a cinematografia nacional passou a adotar fórmulas cada vez mais populares para garantir o sucesso de seus filmes e acabou se submetendo aos constrangimentos das grandes produções. A partir de então, o trânsito entre cineastas e a televisão se tornou mais intenso.

Walter Lima Júnior, por sua vez, sabia que seus trabalhos televisuais serviam para atender à nova lógica que se impunha, mas acreditava no impacto que suas obras poderiam causar no povo brasileiros e, por isso, também, aceitava os trabalhos na televisão. Por isso, preocupava-se com o tipo de linguagem adotada. Mesmo surpreso com a liberdade que encontrou na televisão e que não era mais possível no cinema, mais patrulhado pela censura, Walter preferiu abdicar do "hermetismo de sua linguagem cinematográfica" em nome de uma maior comunicação com o público brasileiro. Walter disse, na mesma entrevista:

Ao realizar o documentário, procurei desenvolver uma linguagem adequada ao público de televisão. Nada de hermético entrou em meu filme. A liberdade de realização que me deram foi por mim condicionada ao tipo de público a que o filme seria destinado. Mas desenvolvi o tema com seriedade. 
Em sete de maio de 1972, a série Globo-Shell Especial exibiu O Som do Povo, de Gustavo Dahl, que "durante muito tempo, por motivos puramente estéticos, implicou com a televisão" ( $O$ Globo, 06/05/1972: 14). Mas, como ele mesmo disse na entrevista, passada essa visão limitada, aceitou os convites da emissora italiana $R A I$ (Radio Televisione Italiana), para onde realizou Il cinema brasiliano: io e lui e Lady Festival em 1970, da TVE, onde fez Banho de Sol (1984), e da Rede Globo, em que dirigiu tanto documentários como programas de ficção. No primeiro filme para a emissora carioca (ele também dirigiu A Promessa (1975) e Gangsters (1977) para o programa Caso Especial), coube a ele tratar da música popular brasileira, "um universo de tema", como declarou. O documentário reunia depoimentos de Vinícius de Moraes, Tom Jobim, Caetano Veloso e Erasmo Carlos, que falavam de suas influências e experiências. Para ilustrar os depoimentos, o cineasta convidou Chico Buarque, Paulinho da Viola, Luís Gonzaga, Ismael Silva, Carlos Lira, Maria Bethânia, Clementina de Jesus, Nelson Cavaquinho, Nara Leão, Roberto Menescal, Roberto Carlos, Ronaldo Bôscoli e os conjuntos Liverpool, The Fevers e Zé Pinel \& O Esquadrão do Vício para entoarem canções marcantes da história da música popular brasileira.

$\mathrm{Na}$ época, empolgado com o mercado que se abria para os cineastas, o diretor de O Bravo Guerreiro (1969) afirmou: "O cinema, como artigo de consumo e hábito da população, foi na essência substituído pela televisão. Não quero dizer com isso que a televisão tenha matado o cinema. Mas roubou muito do cinema. E porque não roubar mais um cineasta?”. Gustavo Dahl continuou a sua argumentação dizendo que o declínio do projeto cinemanovista como uma prática política se deveu ao excesso de "formalismo e de preciosismos" que acabaram afastando o público. Dessa maneira, a preocupação com uma politização, num sentido revolucionário, da arte deu lugar às exigências da ordem capitalista. Os cineastas precisavam se adaptar à nova realidade. Revendo sua trajetória, Gustavo lamentou:

Infelizmente criei uma imagem de diretor de filmes de arte, mas o que quero fazer são filmes musicais ou melodramas históricos. Fazer filmes para televisão, também está no meu esquema. Quem faz cinema está ligado a uma entidade que se chama imagem, da mesma forma que a televisão, as histórias em quadrinhos e a pintura também estão ligadas a ela. 
Todavia, abismado com a diferença de se trabalhar com cinema e com televisão, o cineasta pondera:

Mas senti um choque quando passei a conhecer mais detalhadamente a relação cinema-televisão. Um cinema artesanal e uma televisão industrial. As pessoas que fazem cinema, em geral fazem cinema por que gostam. Em televisão, vi algumas pessoas trabalhando com o mesmo espírito de um operário na linha de montagem, sem curtir o trabalho. E, afinal, a televisão é uma coisa maravilhosa para se curtir.

Se as impressões do momento em que trabalhou para a Rede Globo, foram extremamente positivas, tempos depois, ao lembrar da experiência, Dahl fez ressalvas. Em entrevista para Filme Cultura em 1981, a notável simpatia com a televisão como meio continuou, mesmo que ele tenha feito ressalvas às limitações de seu trabalho na Rede Globo: "No dia seguinte em que o especial [O Som do Povo] foi ao ar, o Boni mandou fazer um famoso memorando dizendo que era péssimo, da concepção a realização" (Filme Cultura, número 38/39, ago/nov/1981: 04). Contrariando o todo-poderoso da Globo, o cineasta achava que o filme era uma grande experiência de comunicabilidade, tanto pela audiência que teve quanto pelos pedidos de empréstimos na filmoteca de Globo-Shell Especial. Sobre sua situação na televisão, ele concluiu: "Na Globo, você se sente assim como o rabo do leão, ou seja, um leãozão enorme e você é a última parte, aquele penacho que tem no rabo do leão e ele usa para sacudir as moscas”.

Aqui está mais evidente consciência que aqueles cineastas tinham de seu papel dentro da televisão. Suas obras se enquadravam num projeto de modernização (que teve a questão da qualidade como uma das fortes características) muito mais abrangente. Os cuidados da Rede Globo se direcionavam para o sucesso de seus produtos e para a manutenção de uma relação harmoniosa com o Estado militar e com os setores conservadores da sociedade. Nesse sentido, a produção daqueles cineastas servia para afirmar, em rede nacional, que os tempos mudaram para melhor. Isto não significou, entretanto, que houve uma desmedida preocupação com o fazer artístico dos que entraram na emissora carioca.

Gustavo Dahl reclamou da falta de estrutura dada pela Rede Globo: “Em $O$ Som do Povo os recursos eram muito poucos: uma câmara, uma nagra para gravar música, uma nagra para mixar, uma meia dúzia de photo-flood. Pelo fato de ser da 
Globo muita gente tocou e cantou de graça e deu depoimentos", o que possibilitou a realização de um roteiro tão ambicioso que, em 50 minutos, pretendia resumir toda a história da música popular brasileira. Mesmo com descontentamento em relação à emissora, Gustavo não deixava de realçar a importância da televisão no Brasil e o seu impacto sobre o cinema:

O cinema brasileiro está perdido entre correr a aventura de um mercado que deteriora e se impor a um meio de maior difusão. Se é para fazer cultura, vamos direto à antena: você vai encontrar certas limitações, como a presença da publicidade ou a latitude do público, mas vai realizar este lado importante que é a comunicação.

Em três de julho de 1972, depois de já ter dirigido Arte Popular, Testemunho de Natal, Pão Nosso de Cada Dia para o programa, O Globo anunciava que Paulo Gil Soares preparava os para o lançamento do novo documentário, O Negro na Cultura Brasileira. A frase "Cineasta ligado ao construtor do Cinema Novo [Glauber Rocha], autor de filmes considerados obras-primas do cinema nacional, Paulo Gil não se deixou envolver pelo intelectualismo crescente do Cinema Novo e foi para a televisão consciente de sua importância como meio de comunicação" abria a matéria do jornal. O também diretor da série Globo-Shell Especial comparou a sua experiência com o cinema com os primeiros contatos com a televisão, de maneira semelhante a Dahl:

Negar a TV é burrice. Memórias do Cangaço [1965] e Proezas de Satanás na Vila de Leva e Traz [1967] foram filmes elogiadíssimos. As faculdades, as escolas, os departamentos culturais davam aulas em cima deles, exibiam discutiam, mas acredito que apenas umas cinco mil pessoas os tenham visto. De uma maneira genérica, o alcance de um filme na televisão é enorme. Pode-se condenar a forma como é feita a TV, mas não ignorá-la como veículo de informação. Não estou interessado em fazer filme para meia dúzia de pessoas. Eu tenho a preocupação de informar e quero que minha informação chegue ao público. Para isso, uso a televisão.

O diretor do célebre documentário Viramundo (1965), para Globo-Shell Especial, Geraldo Sarno realizou Semana da Arte Moderna. Em comemoração ao aniversário de 50 anos do movimento modernista, o filme narra a sua história e especula acerca das suas heranças na cultura contemporânea, enfocando o Tropicalismo na música, no cinema, no teatro e na literatura. Foram entrevistados Márcio da Silva Brito, José Celso Martinez Correia, Joaquim Pedro de Andrade e Gilberto Gil. Definindo-se como "um homem de cinema em face da televisão", Sarno, para O Globo (14/07/1972: 12), disse: 


\begin{abstract}
Nunca me impus barreira entre cinema e televisão, pois essa barreira, na realidade, não existe. Em todas as emissoras, o cinema está presente em grandes programações. E na Globo, particularmente, temos os documentários por ela produzidos. O cineasta pode e deve ser participante da televisão: Rosselini e Godard fazem filmes especiais para a TV.
\end{abstract}

Ao se deparar com o contexto que permitiram tais situações e declarações, Hollanda (1992: 92) lastima o fato de cineastas do Cinema Novo, que haviam produzido obras extremamente críticas e questionadoras da sociedade nos anos 1960, na década posterior, tenham se limitado a aderir às exigências do mercado e à política cultural do Estado. O nacional-popular, uma questão revolucionária, havia passado a ser uma problemática do mercado que, no lugar de mostrar fenômenos contraditórios, preferia os estereótipos. A autora revela a ingenuidade no processo, em que os artistas acreditavam que, entrando no sistema, poderiam transformá-lo, quando, na verdade, estavam abastecendo-o de produtos "maduros" e "qualificados". Para ela, o sistema é capaz de absorver e de amortecer todo tipo de contestação política, perdendo o "contato com o povo" as obras de arte engajadas passaram a se restringir a um circuito de espetáculo e se redundaram num "simulacro de militância". Então, Hollanda (1992: 93) sentencia: "As obras engajadas vão-se transformando num rentável negócio para as empresas da cultura: a contestação, integrada às relações de produção cultural estabelecidas, transforma-se novamente em reabastecimento do sistema onde não consegue introduzir tensões”.

Acredito que a percepção da autora esteja correta ao apontar que os artistas politicamente engajados formados nos anos 1960 passaram a produzir para as empresas de cultura produtos de bom retorno financeiro e cultural, garantindo status tanto a empresa quanto a eles mesmos. É certo que Hollanda está mostrando o seu descontentamento com o fato de a arte revolucionária ter perdido o seu "espírito revolucionário". Tal colaboração, portanto, foi possível num momento da frustração e da repressão causado pela implementação e pela consolidação do Estado militar, quando foi preciso encontrar novos caminhos para a produção artística.

Percebe-se naquela afirmação de Hollanda uma aceitação do conceito de indústria cultural como foi formulado por Theodor Adorno e Max Horkheimer (1985: 114), para quem a sua existência não passa de um negócio e que os produtos advindos dela só servem para difundir "uma ideologia destinada a legitimar o lixo cultural a 
que propositalmente produzem". A autora se refere ao fato de a indústria cultural ter levado de maneira desajeita a arte para a esfera do consumo, uma vez que a primeira é extremamente inflexível em relação à variação de estilos e à liberdade da autoria, produzindo "o mais do mesmo", conferindo a tudo um ar de semelhança. Diferente disso, pergunto-me se é possível falar da inexistência de tensões observando unicamente a apropriação dos cineastas sem analisar o que eles produziram e como vivenciaram aquelas novas relações.

Fazendo lembrar tal postura, Ortiz (2001) demonstra como o "nacional" e o "popular", conceitos que nos anos 1960 tinham vocação revolucionária, passam a se “despolitizar”, quando absorvidos pelos novos veículos de comunicação de massa, especialmente pela televisão. A preocupação dele é a de compreender em que medida o advento de uma indústria cultural vem modificar o panorama dessa discussão. Para ele, a televisão equaciona a identidade nacional em termos mercadológicos, ao interligar consumidores em potencial espalhados pelo país. Mas isto só foi possível, principalmente, a partir dos anos 1970, quando as emissoras brasileiras começaram a aumentar consideravelmente as produções nacionais, acompanhando o ufanismo da modernização conservadora da época. É neste momento que autor percebe na televisão uma maciça presença de artistas da esquerda brasileira que se diziam e eram tidos como "não alienados" e como "engajados com a realidade". Ortiz (2001: 181), assim, demonstrou:

Os intelectuais do nacional-popular não perceberam é que eles são presas de um discurso que se aplicava a uma outra conjuntura da história brasileira, e são, portanto, incapazes de entender que a ausência da contradição os impede inclusive de tomar criticamente consciência da sociedade moderna em que vivem.

Como está explícito neste trecho, o autor não titubeia em defender a noção de ideologia no sentido de falsa consciência. Ele pressupõe a existência de um universo autônomo, separado da realidade, que é a ilusão. A contradição, neste sentido, só seria resultado do enfrentamento entre o real e o ilusório. Então, para o autor, não se pode aceitar que o realismo das obras dos artistas da revolução que foram para a televisão é idêntico à realidade da sociedade, pois afirmar isto é acreditar que a identidade nacional tenha se efetivado. Na sua concepção, aqueles artistas não haviam atentado para tal problema, uma vez que, deixando a oposição de 
lado, a própria noção de alienação perderia todo o sentido. Na televisão, eles haviam se alienado, por acreditarem no poder transformador daquela indústria.

Quando voltamos a algumas impressões daqueles cineastas, faz sentido a argumentação de Ortiz (2001: 180):

O que chama a atenção no discurso que justifica esse tipo de produção é que as razões de mercado se encontram encobertas, legitimadas por uma perspectiva superficialmente política e nacionalista. Política, porque muitos intelectuais da televisão, provenientes dos movimentos culturas dos anos 50 e 60, carregam com eles a mesma ideologia sobre o "povo alienado", só que agora aplicado a um contexto inteiramente deslocado. (...). Nacionalista, na medida em que a proposta de construção de uma linguagem, de uma dramaturgia brasileira, encontra na televisão um espaço para se realizar.

Tal argumentação faz sentido, se adotarmos a rígida definição distinção entre ideologia e utopia dada por Karl Mannheim (1950), em que a primeira aparece relacionada à promoção de mudanças, enquanto a outra aparece como a que produz a conservação da ordem. Elas não convivem, a não ser que seja pelo confronto. $\mathrm{Na}$ concepção de Mannheim à ideologia se contrapõe a utopia, que expressa a "visão de mundo" de certos grupos oprimidos, empenhados em transformar radicalmente a sociedade, uma vez que a nega. A ideologia, portanto, seria uma formação intrinsecamente conservadora.

Essa postura demanda uma análise do processo que levou o envolvimento de cineastas identificados com o Cinema Novo com a televisão como essencialmente infra-estrutural. A nova realidade econômica determinou a aproximação, a alienação e o deslumbre deles em relação às possibilidades da nova mídia e teriam esquecido suas formações. Ela não dá conta das mudanças, se não for pela oposição entre o "real" e o "ilusório". Como outros artistas revolucionários (Dias Gomes, Oduvaldo Vianna Filho, Paulo Ponto, Ferreira Gullar), os cinemanovistas também teriam se alienado e perdido a consciência de outrora.

Todavia, se podemos especular que houve apagamentos na submissão daqueles artistas à lógica da indústria cultural, também podemos acreditar que também houve resquícios daquela formação nas obras que passaram a servir para consolidar a ordem. Devemos tomar o cuidado para não acreditarmos que nada escapa às dinâmicas sociais hegemônicas. Se aceitarmos, como propõe Raymond 
Williams (1979; 1997; 2000), que tais dinâmicas não são somente constituídas por determinações e continuidades, mas também por tensões, por conflitos, resoluções e irresoluções, inovações e mudanças reais, não podemos destituir dos sujeitos concretos que participam de dadas dinâmicas a capacidade de assumir diferentes posições, que não são necessariamente reprodutoras da "ideologia dominante" seus outros: o dominando, o alternativo, o emergente. A dominância só ocorre porque outras práticas, sentimentos e pensamentos lhe escapam. Ou melhor: o hegemônico é constituído pela pluralidade.

Nessa perspectiva, o binarismo não é válido. O fato de não conceber as ideologias como um amálgama, inteiramente complexo, que articula formações diferenciadas que precisam ser continuamente renegociadas e resolvidas. Num texto bastante importante, Stuart Hall (2003) critica o apego das formulações mais clássicas um apego à concepção de ideologia como "falsa consciência". Identificada exclusivamente com a classe dirigente, ela aparece como "distorção" da realidade. Hall questiona sobre até que ponto explicações unilaterais como essas podem explicar práticas sociais concretas. Para ele, raramente, o que acontece na sociedade se encaixa na distinção entre "falso" e "verdadeiro". Como argumenta o autor, um estudo cultural crítico deve estar atento às "sutis variações" presentes nos discursos dos sujeitos concretos que constituem o terreno das lutas socioculturais de uma dada época. Não se pode abstraí-los em relação às praticas sociais que os produziram e dos locais institucionais em que foram elaborados.

Como apresentei, a presença de cinemanovistas na televisão foi possível tanto pela busca de uma "televisão de qualidade" livre do grotesco quanto pelo contexto de produção cinematográfica no Brasil, por conta do recrudescimento da censura e repressões militares. Para a Rede Globo, os cineastas estavam conscientes de que faziam parte de uma mudança de lógica de programação da emissora, mas não perderam a oportunidade de se comunicar com povo brasileiro. A televisão usou os cineastas, mas também foi usada por eles.

Quando voltamos àquelas impressões, além do generalizado fascínio, existia a percepção de que suas entradas na nova mídia estavam relacionadas à "crise do cinema brasileiro" e à criação de uma "nova mentalidade para a televisão brasileira" como disse Walter Lima Júnior. Mesmo aproveitando a nova possibilidade de 
emprego aberta, os cineastas não deixaram de fazer críticas. Gustavo Dahl e Walter Lima Júnior, apesar de reconhecerem esses problemas, percebiam a capacidade do meio de comunicar com o povo brasileiro ("se é para fazer cultura, vamos direto à antena”, disse entusiasmado Dahl; "[os homens do cinema brasileiro vão] realizar filmes sobre a realidade de nosso país para serem visto pelo público de nosso país", comemora Walter). Como os demais, Paulo Gil Soares e Geraldo Sarno acreditavam que não deveria haver barreira entre o cinema e a televisão. Os cineastas não deveriam negar a televisão, fingir que ela não existe, mas reconhecê-la e utilizá-la.

Em relação à entrada de artistas e intelectuais de esquerda na televisão, Celso Frederico (1999) retoma o diagnóstico de Fredric Jameson (2003), para entender o "desaparecimento da esquerda", e acaba dando mais nuanças à questão. Frederico mostra que a forte presença da esquerda na cultura brasileira só era possível quando ela não era um espaço subjugado pela lógica do mercado. A partir do momento em que isto acontece, a "quase autonomia", conseguida por sua manutenção como um pólo de resistência, foi destruída pela lógica cultural do capitalismo tardio, que funde o capital ao cultural. Obras que originalmente têm um sentido contestador são usadas para legitimar à lógica da cultura do consumo. Para ele, com a crescente mercantilização da cultura, a esquerda ficou enfraquecida e precisou encontrar novos meios de fazer política.

Sergio Paulo Rouanet numa resenha ao livro A moderna tradição brasileira, de Renato Ortiz, problematizou: "O nacional-popular de mídia não é ideologia, mas crítica da ideologia, ou antes, é uma ideologia que é ao mesmo tempo mistificada como toda ideologia, desmistificadora, porque é paródia de uma prática que não se sabe ideológica" (Folha de S. Paulo, 13/o3/1988: 03). Motivado por essa percepção, Ridenti (2000: 324) propõe:

Essa relação [entre artistas da revolução e a televisão] tem sido vista ora como capitulação ideológica diante da burguesia - cuja dominação os artistas ajudariam a garantir, contribuindo para gerar uma ideologia nacional-popular de mercado, legitimadora da modernização conservadora da ordem social vigente -, ora como possibilidade de levar uma visão crítica ao telespectador, contribuindo para mudanças sociais. Entre essas duas visões opostas, parece haver espaço para uma série de nuanças. 
Usando um outro texto de Jameson, "Reificação e utopia na cultura de massa" (1995), Ridenti afirma a importância de se perceber a participação de artistas da revolução na televisão e os produtos originários dela em suas dimensões legitimadoras e contestadoras da ordem, sendo ao mesmo tempo e num certo ponto ideológicas e utópicas. Jameson (1995: 35) entende que as primeiras dizem respeito ao "modo como vivemos" e as outras, ao "modo como deveríamos viver". Embora de forma amiúde distorcida e recalcada, a indústria cultural contém, como impulso subjacente, as utopias de uma época, além das ideologias. Nesse sentido, a ideologia deve ser estudada, então, como uma totalidade diferenciada, constituída por diferentes posições, discursos e práticas que podem ser conflituosas. Certamente, essa perspectiva ganha ainda mais materialidade, quando são estudas produções

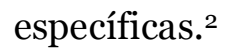

Desse modo, verificamos que aquelas impressões revelam tanto a aceitação e a contemplação quanto o questionamento e o espanto em relação à nova realidade. A televisão agradava como veículo pela sua capacidade de atingir um público bem mais amplo que o possível pelo cinema. A televisão tinha objetivos comerciais e queria mudar a sua imagem, criar "uma nova mentalidade". A televisão era um novo mercado de trabalho. A televisão foi espaço da transformação, do refluxo e da continuidade da "vontade de redescobrir o Brasil e o seu povo" por parte dos cineastas oriundos do Cinema Novo, formados sob o signo da iminente revolução brasileira que, nos anos 1960, assolava o pensamento e a ação de inúmeros artistas e intelectuais.

Então, o trânsito entre cineastas brasileiros e a televisão ajuda a entender que, se, por um lado, a industrialização da cultura tem aproximado ou até mesmo amalgamado campos relativamente autônomos, por outro, ela não impediu o posicionamento crítico dos seus envolvidos. É preciso estudar como a entrada deles na televisão produziu consciências - e elas foram verdadeiras, reais, polifônicas.

\footnotetext{
${ }^{2}$ Dentro dessa perspectiva, apresentei o trabalho "Coutinho na TV: um cineasta de esquerda fazendo jornalismo" no Congresso Brasileiro de Ciências da Comunicação (Intercom), vencedor do Prêmio Francisco Morel concedido pelo mesmo congresso. Ainda em 2007, o texto será publicado no livro Ícones da civilização midiática, organizado pelos professores José Marques de Melo e Raquel Paiva e editado pela Editora Mauad.
} 
Como um terreno de lutas, o mercado não é dotado de uma única postura ideológica, mas de muitas delas em constante conflito.

\section{Referências bibliográficas}

ADORNO, Theodor e HORKHEIMER, Max. Dialética do Esclarecimento: fragmentos filosóficos. Rio de Janeiro: Jorge Zahar Editor, 1985 [1944].

BARBOSA, Marialva e RIBEIRO, Ana Paula Goulart. "Telejornalismo na Globo: vestígios, narrativa e temporalidade”. In BOLAÑO, César e BRITTOS, Valério Cruz (orgs). Rede Globo: 40 anos de poder e hegemonia, p. São Paulo: Paulus, 2005.

BERNARDET, Jean-Claude. Brasil em tempo de cinema. Rio de Janeiro, Civilização Brasileira, 1967.

. O autor no cinema: a política dos autores - França, Brasil anos 50 e 60.

São Paulo: Brasiliense, 1994.

BOURDIEU, Pierre. A economia das trocas simbólicas. São Paulo: Perspectiva, 2001 [1974].

FREDERICO, Celso. “A política cultural dos comunistas”. In: MORAES, João Quartim de. História do marxismo no Brasil. Teorias. Interpretações. São Paulo: Editora da Unicamp, 1999.

FREIRE FILHO, João. "Memórias do mundo-cão: 50 anos de debate sobre o nível da TV no Brasil”. In: LOPES, Maria Immacolata Vassallo e BUONNANO, Milly (orgs.). Comunicação Social e Ética: Colóquio Brasil-Itália, p. 164-18o. São Paulo: INTERCOM, 2005.

HALL, Stuart. "O problema da ideologia: o marxismo sem garantias". In: Da Diáspora: identidades e mediações culturais, p. 265-293. Belo Horizonte: Editora da UFMG, 2003 [1983].

HOLLANDA, Heloísa Buarque de. Impressões de viagem: CPC, vanguarda e desbunde - 1960/1970. Rio de Janeiro: Editora Rocco, 1992 [1978].

e GOLÇALVES, Marcos. Cultura e participação nos anos 60. Rio de Janeiro: Brasiliense, 1982.

JAMESON, Fredric. Pós-modernismo: a lógica cultural do capitalismo tardio. São

Paulo: Editora Ática, 2003 [1991].

. "Reificação e utopia na cultura de massa", p. o9-35. In: . As marcas do visível. Rio de Janeiro: Edições Graal, 1995 [1979]. 
JORGE, Marina Soler. "Cinema Novo e Embrafilme: cineastas e Estado pela consolidação da indústria cinematográfica brasileira”. Dissertação de Mestrado em Sociologia. Campinas: Unicamp, 2002.

KEHL, Maria Rita. "Eu vi um Brasil na TV”. In COSTA, Alcir Henrique; KHEL, Maria Rita e SIMÕES, Inimá. Um país no ar: a história da TV brasileira em três canais. São Paulo, Brasiliense/Funarte, p.169-276, 1986.

MANNHEIM, Karl. Ideologia e utopia. Porto Alegre: Globo, 1950 [1929].

MICELI, Sergio. “O papel político dos meios de comunicação de massa”. In: SCHWARTZ, Jorge e SOSNOWSKI, Saul. (orgs.). Brasil: o trânsito da memória, p. 41-67. São Paulo: EDUSP, 1994.

MIRA, Maria Celeste. Circo eletrônico - Sílvio Santos e o SBT. São Paulo: Olho D’Água/Loyola, 1995.

NAPOLITANO, Marcos. “A arte engajada e seus públicos (1955/1968)”. In: Estudos Históricos, Rio de Janeiro, v. 28, p. 103-124, 2001.

ORTIZ, Renato. A moderna tradição brasileira - cultura brasileira e indústria cultural. São Paulo: Brasiliense, 2001 [1988].

RAMOS, José Mário Ortiz. Cinema, Estado e lutas culturais (anos 50/60/70). São Paulo: Paz e Terra, 1983.

. Cinema, televisão e publicidade: cultura popular de massa no Brasil dos anos 1970-1980. São Paulo: Annablume, 2004 [1995].

RIDENTI, Marcelo. “Artistas e intelectuais no Brasil pós-1960”. In Tempo Social, Revista de Sociologia da USP, p. 81-110. São Paulo, USP, 2005.

. Em busca do povo brasileiro: artistas da revolução, do CPC à era da TV . São Paulo: Editora Record, 2000.

SACRAMENTO, Igor. "Coutinho na TV: um cineasta de esquerda fazendo jornalismo" In: XXIX Congresso Brasileiro de Ciências da Comunicação - Intercom. Brasília, 2006.

SALLES GOMES, Paulo. Cinema: trajetória no subdesenvolvimento. São Paulo: Paz e Terra, 1996 [1973].

SIMÕES, Inimá. Roteiro da intolerância: a censura cinematográfica no Brasil. São Paulo: Editora Senac, 1999.

SODRÉ, Muniz. A comunicação do grotesco: um ensaio sobre a cultura de massa no Brasil. Petrópolis: Vozes, 1978 [1972].

WANDERLEY, Sônia. "A construção do silêncio: a Rede Globo nos projetos de controle social e cidadania (décadas 1970/1980)". Dissertação de Mestrado em História. Niterói: UFF, 1995.

WILLIAMS, Raymond. Cultura. Rio de Janeiro: Paz e Terra, 1992 [1981]. . Marxismo e literatura. Rio de Janeiro: Jorge Zahar Editor, 1979 [1977]. . Problems in materialism and culture. London: Verso, 1997 [1980].

XAVIER, Ismail. O cinema brasileiro moderno. São Paulo: Paz e Terra, 2001. 